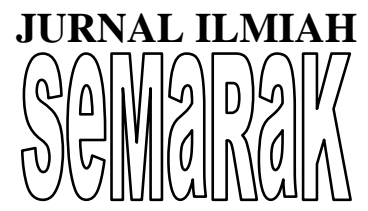

P-ISSN 2615-6849, E-ISSN 2622-3686

Jurnal Semarak,Vol. 2,No.1, Februari 2019, Hal (111-129)

@Prodi Manajemen Fakultas Ekonomi Universitas Pamulang

\title{
ANALISIS PENGARUH KEPEMILIKAN INSTITUSIONAL, PROFITABILITY DAN FIRM SIZE TERHADAP PRICE EARNING RATIO (PER) PADA PERUSAHAAN LQ-45 PERIODE $2011-2013$
}

\author{
Roni Heryatno \\ Staf Pengajar Fakultas Ekonomi Universitas Pamulang \\ Email: roni.heryatno@gmail.com
}

\begin{abstract}
ABSTRAK
Tujuan dari penelitian ini adalah "untuk mengetahui penngaruh anatara kepemilikan institusional terhadap price earniing ratio, "untuk mengetahui penngaruh anataraa profitability terhadap price earniing ratio, "untuk mengetahui penngaruh anataraa firm size terhadap price earniing ratio, "untuk mengetahui pengaruh seacara simultan antara kepemilikan manajerial, kepemilikan institusionjal, profitability terhadap price earniing ratio". Penelitian ini menggunakan data sekunder yang didapat berdasarkan laporan keuangan di perusahaan LQ 45 yang terdaftar di bursa efek Indonesia (BEI) pada periode 2011 - 2013. Sampel dalam penelitian ini adalah sebanyak 23 perusahaan. Hasil penelitian menunjukkan bahwa terdapat pengaruh secara parsial antara kepemilikan institusional dan profitability berpengaruh terhadap price earning ratio sedangkan variabel firm size tidak mempengaruhi price earning ratio. Hasil penelitian ini juga menunjukkan bahwa kepemilikan institusional, profitability dan firm size berpengaruh terhadap price earning ratio secara bersamasama (simultan). "Pada koefisien determinasi terdapat pengaruh sebesar 42,6\% yang mempengaruhi price earning ratio yang dijelaskan oleh variable kepemilikan institusional, profitability dan firm size, sedangkan sisanya 57,4\% dipengaruhi oleh variabel lain yang tidak terdapat dalam penelitian ini”.
\end{abstract}

Kata kunci: kepemilikan institusional, profitability, firm size.

ABSTRACT

The purpose of this research is "to know the influence of interrelations between institutional ownership against the price earning ratio," to find out penngaruh anataraa earniing price against profitability ratio, "to know the penngaruh between firm size against price ratio of earniing, "to know the influence of simultaneous seacara between the managerial ownership, ownership of the institusionjal, the earniing ratio price against profitability". This study uses secondary data obtained based on the financial statements of the company in the LQ 45 listed in Indonesia stock exchange (BEI) in the period 2011-2013. The sample in this research is as much as 23 companies. The results showed that there was a partial influence between institutional ownership and profitability to price earning ratio while the firm size variables does not affect the price earning ratio. The results of this research also suggests that institutional ownership, profitability and the firm size effect on price earning ratio simultaneously (simultaneous). "There is determination of the coefficients On the influence of $42.6 \%$ that affect price earning ratio explained by variable institutional ownership, firm size and profitability, while the remaining $57.4 \%$ is affected by other variables that are not There is in this research".

Keywords: institutional ownership, profitability, firm size

\section{PENDAHLUAN}

\section{A. Lataar Beelakang Penelitian}

"Pendirian sebuah perusahaan harus memiliki tujuan yang jelas. Ada beberapa hal yang mengemukakan tentang tujuan pendirian suatu perusahaan. Tujuan perusahaan yang pertama adalah untuk mencapai keuntungan maksimal atau laba yang sebesar-besarnya". Maksud dari suatu Syarikat kedua ingin mencapai kejayaan pemilik syarikat atau pemegang saham. "Sedangkan tujuan perusahaan 


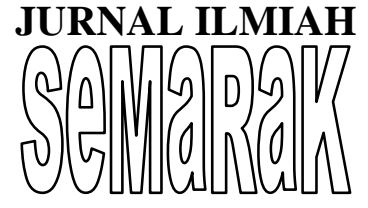

yang ketiga adalah memaksimalkan nilai perusahaan yang tercermin pada harga sahamnya". Tiga objektif syarikat sebenarnya tidak jauh berbeza. "Hanya saja penekanan yang ingin dicapai oleh masing-masing perusahaan berbeda antara yang satu dengan yang lainnya" (Marrtono dan Hrjito, 2005:2).

"Akhir-akhir ini, penciptaan nilai untuk pemegang saham sebuah perusahaan diterima secara luas sebagai tujuan perusahaan telah dimasukkan ke dalam literature manajemen strategik melalui apa yang disebut value-based planning (Hax et al., 1984)", "Sehingga para pemegang saham akan mencoba menginvestasikan modalnya kepada perusahaan tersebut (Haruman, 2008:56)”.

"Naik turunnya nilai perusahaan salah satunya dipengaruhi oleh struktur kepemilikan. Struktur kepemilikan sangat penting dalam menentukan nilai perusahaan. Dua aspek yang perlu dipertimbangkan ialah (1) konsentrasi kepemilikan perusahaan oleh pihak luar (outsider ownership concentration) dan (2) kepemilikan perusahaan oleh manajemen (management ownership). Pemilik perusahaan dari pihak luar berbeda dengan manajer karena kecil kemungkinannya pemilik dari pihak luar terlibat dalam urusan bisnis perusahaan sehari-hari” (Rejeeki daan Haartono, 2007:23).
"Peningkatan nilai perusahaan yang tinggi merupakan tujuan jangka panjang yang seharusnya dicapai perusahaan, yang akan tercermin dari harga pasar sahamnya, karena penilaian investor terhadap perusahaan dapat diamati melalui pergerakan harga saham perusahaan". Salah satu faktor yang mempengaruhi harga saham ialah keupayaan syarikat membayar dividen. "Dalam proses memaksimalkan nilai perusahaan akan muncul konflik kepentingan antara agent dan principal (pemilik perusahaan) yang sering disebut agency problem". Sering sekali perkara yang biasa berlaku di syarikat-syarikat yang ejen dan pengetua mempunyai tujuan dan kepentingan yang saling bertentangan. "Agen atau pihak manajemen lebih mementingkan kepentingan pribadinya dan tidak sesuai tujuan perusahaan yaitu mensejahterakan pemilik perusahaan dan meningkatkan nilai perusahaan. Perlakuan manajer ini akan mengakibatkan penambahan biaya perusahaan yang tentunya akan mempengaruhi nilai perusahaan. Timbulnya konflik perbedaan tujuan serta kepentingan antara manajer dengan pemilik perusahaan inilah yang pada akhirnya melatarbelakangi penerapan Good Corporate Governance (Anggraini, 2013:2)".

Berdasarkan penjelasan yang diterangkan di atas, penulis berminat untuk menjalankan penyelidikan mengenai 


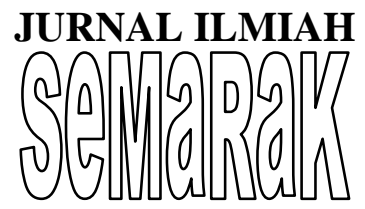

kesan pemilikan institusi, keuntungan dan saiz firma pada nisbah pendapatan harga.

Kajian ini dijalankan dengan tujuan untuk mengetahui sama ada terdapat kesan pemilikan institusi, keuntungan dan pembolehubah saiz firma pada nisbah pendapatan harga. Kemudian penyelidikan akan diterjemahkan ke dalam kajian yang berhak "Analisis Pengaruh Kepemilikan Institusional, Profitability Dan Firm Size Terhadap Price Earning Ratio (PER) Pada Perusahaan LQ-45 Periode 2011 2013".

\section{B. Rummusan Massalah}

"Berdasarkan kajian latar tentang faktor - faktor yang mempengaruhi nilai buku harga yang diuraikan oleh penulis, maka rumusan masalah yang dibahas antara lain":

1. Appakah terdapart penngaruh anatara kepemilikan institusional terhadap price earniing ratioo?

2. Appakah terdapart penngaruh anataraa profitability terhadap price earniing ratioo?

3. Appakah terdapart penngaruh anataraa firm size terhadap price earniing ratio ?

4. Bagaimana pengaruh kepemilikan manajerial, kepemilikan institusionjal, profitability terhadap price earniing ratio?

\section{Tuujuan Peneelitian}

"Berdasarkan dari latar belakang dan rumusan masalah dan tujuan dalam penelitian ini adalah seperti berikut":
1. Untuk meengetahui penngaruh anatara kepemmilikan institusional terrhadap price earniing ratioo.

2. Untuk mengetahui penngaruh anataraa profitability terhadap price earniing ratioo.

3. Untukk menggetahui penngaruh anataraa firmm sizze terhadap price earniing raatio.

4. Untuk mengetahui pengaruh seacara simultan antara kepemilikan manajerial, kepemilikan institusionjal, profitability terhadap price earniing ratio.

\section{TINNJAUAN PUSSTAKA}

\section{A. Teorri Agennsi (Agencyy Theoory)}

"Teori keagenan (agency theory) merupakan sekelompok gagasan mengenai pengendalian organisasi yang didasarkan pada keyakinan bahwa pemisahan kepemilikan dengan manajemen menimbulkan potensi bahwa keinginan pemilik diabaikan ketika pemilik (manajer) mendelegasikan otoritas pengambilan keputusan ada pihak lain, terdapat hubungan keagenan antara kedua belah pihak" (Roobinson, 2008:47).

"Teori agensi atau teori keagenan muncul ketika terdapat dua pihak yang saling terkait dimana pihak pertama setuju untuk memakai jasa pihak tertentu. Jensen dan Meckling dalam Sari (2011:4)", menyatakan bahwa teori keagenan mendeskripsikan pemegang saham sebagai prinsipal dan manajemen sebagai agen. 
"Manajemen merupakan pihak yang dikontrak oleh pemegang saham untuk bekerja demi kepentingan pemegang saham. Untuk itu manajemen diberikan sebagian kekuasaan untuk membuat keputusan bagi kepentingan terbaik pemegang saham".

"Teori keagenan mengasumsikan bahwa semua individu bertindak atas kepentingan mereka sendiri dan agen (manajer perusahaan) diasumsikan menerima kepuasan bukan saja dari kompensasi keuangan tetapi juga dari syarat-syarat yang terlibat dalam hubungan keagenan, seperti jumlah waktu luang, kondisi kerja yang menarik, keanggotaan klub dan jam kerja yang fleksibel". Menurut Briggham dan Housston (2009:54), hubungan keagenan dapat timbul di antara:

\section{Pemegang Saham dengan Pengurus}

Masalah agensi dapat timbul jika pengurus menempatkan tujuan dan kesejahteraan mereka sendiri pada posisi yang lebih tinggi dari kepentingan pemegang saham. Menurut Jensen dan Meckling (1976), masalah agensi berpotensi terjadi apabila proporsi kepemilikan saham syarikat kurang dari seratus persen sehingga para pengurus cenderung bertindak untuk mengejar kepentingan mereka sendiri daripada memaksimalkan nilai perusahaan dalam membuat keputusan pendanaan. Tindakan pengurus oportunistik akan meningkatkan kos syarikat dan mengurangkan kemakmuran para pemegang saham.

\section{Pemegang saham (melalui pengurus)} dengan pemiutang.

Pihak pemiutang mempunyai tuntutan untuk sebahagian daripada aliran tunai syarikat untuk pembayaran faedah dan hutang utama. Mereka mempunyai tuntutan untuk aset syarikat apabila syarikat itu muflis. Apabila syarikat mengalami muflis, keputusan harus diambil dengan segera untuk mengatasi keadaan, sama ada untuk melikuidasi syarikat dengan menjual semua aset atau melakukan penyusunan semula. Pengurusan perlu bertindak segera dan khususnya pengurus memilih untuk menyusun semula dengan tujuan mengekalkan pekerjaan mereka. Keputusan pengurus ini tentu memberi kesan kepada pemegang saham atau pemiutang atau kedua-dua pihak.

\section{B. Teorri Sinyyal (Signnalling Theeory)}

"Teori sinyal (signaling theory) yang digunakan untuk menjelaskan bahwa pada dasarnya laporan keuangan dimanfaatkan perusahaan untuk memberi sinyal positif maupun negatif kepada pemakainya. Demikian juga dengan teori agensi yang digunakan untuk menjelaskan bahwa laporan keuangan merupakan akibat 


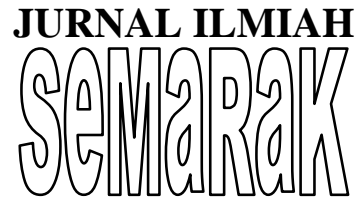

pemisahan kepemilikan dan kepengelolaan perusahaan (Sulistyanto, 2008:65)".

"Teori sinyal merupakan kenaikan dividen sering diikuti dengan kenaikan harga saham, dan sebaliknya. Fenomena ini setidaknya memperlihatkan bahwa investor lebih menyukai dividen daripada capital gains". Modigliani dan Miller berhujah bahawa kenaikan dividen ini merupakan isyarat kepada pelabur bahawa pengurusan syarikat meramalkan pendapatan yang baik pada masa akan datang.

"Sebaliknya, suatu penurunan dividen atau kenaikan dividen di bawah kenaikan normal (biasanya) diyakini investor sebagai sinyal bahwa perusahaan akan menghadapi masa sulit di waktu mendatang" (Sawir, 2004:147).

\section{Kinerrja Keuaangan Perussahaan}

"Dalam sebuah perusahaan kinerja adalah hal yang teramat sangat penting dan perlu mendapatkan perhatian lebih. Kinerja perusahaan merupakan indikator yang penting tidak hanya bagi pihak perusahaan namun juga untuk para pemangku kepentingan, misalnya investor. Kinerja perusahaan menunjukkan kemampuan manajemen dalam perusahaan untuk mengelola semua sumber daya yang ada dalam perusahaan untuk mencapai tujuan perusahaan".

"Laporan keuangan merupakan hasil akhir dari proses akuntansi. Sebagai hasil akhir dari proses akuntansi, laporan keuangan memberikan informasi yang berguna untuk pengambilan keputusan berbagai pihak, misalnya pemilik perusahaan atau kreditor (Suwiknyo, 2010:42)".

"Dua laporan keuangan yang umumnya memakai dasar akrual adalah laporan keuangan laba rugi (profit and loss statement) dan neraca (balance sheet). Sementara itu, laporan arus kas (cash flow statement) adalah laporan keuangan yang juga didasarkan atas dasar akrual, tetapi telah disesuaikan sedemikian rupa sehingga mencerminkan arus kas yang sebenarnya" (Mardiyanto, 2008:27).

Brigham dan Houston (2010:87) menjelaskan bahwa "neraca (balance sheet) adalah suatu laporan mengenai posisi keuangan perusahaan pada suatu titik tertentu)". Sedangkan menurut Revee, dkk (2009:22) "neraca merupakan daftar asset, kewajiban, dan ekuitas pemilik pada waktu tertentu, biasanya pada tanggal terakhir dari bulan atau tahun tertentu". "Neraca terdiri dari dua sisi dimana sisi sebelah kanan menyajikan data aktiva yang dimiliki oleh perusahaan, sedangkan sisi sebelah kiri menyajikan kewajiban dan ekuitas perusahaan yang mencerminkan klaim terhadap aktiva. Neraca merupakan laporan keuangan yang menggambarkan kondisi finansial perusahaan pada suatu waktu tertentu".

"Neraca disebut juga sebagai gambaran kondisi keuangan perusahaan yang bersifat snapshot atau gambaran sesaat seperti layaknya sebuah foto, karena neraca hanya memberikan 
informasi posisi keuangan perusahaan pada saat tertentu saja" (Tandelilin, 2010:365-366).

"Neraca merupakan laporan yang mengungkapkan posisi keuangan (kekayaan) dari suatu perusahaan pada tanggal tertentu mencakup aktiva (asset), utang (liability) dan ekuitas (equity). Hubungan ketiganya disebut sebagai persamaan akuntansi, yakni aktiva sama dengan utang ditambah ekuitas" (Mardiyanto, 2008:27).

"Mengenai laporan laba rugi (income statement), Brigham dan Houston (2010:93) menjelaskan bahwa "laporan laba rugi (income statement) adalah laporan yang merangkum pendapatan dan beban perusahaan selama suatu periode akuntansi, biasanya satu kuartal atau satu tahun." Lebih lanjut Revee, dkk (2009:22) menjelaskan bahwa "laporan laba rugi merupakan ringkasan dari pendapatan dan beban untuk suatu periode waktu tertentu, seperti satu bulan atau satu tahun". Dalam penyata pendapatan, jualan bersih dibentangkan di bahagian atas laporan, manakala kos operasi, faedah, dan cukai digunakan sebagai potongan untuk menentukan jumlah pendapatan bersih yang tersedia kepada para pemegang saham. Komponen dalam penyata pendapatan terdiri daripada, pendapatan bersih atau kerugian bersih, pendapatan, perbelanjaan, kos pengeluaran dan kos barang yang dijual" (Fuad, dkk, 2006:167).

\section{Rasio Keuangan}

"Rasio Keuangan adalah angka yang diperoleh dari hasil perbandingan dari satu pos laporan keuangan dengan pos lainya yang mempunyai hubungan yang relevan dan signifikan. Teknik ini sangat lazim digunakan para analisis keuangan. Rasio keungan adalah dasar untuk menilai dan mengarahkan prestasi operasi perusahaan. Disamping itu, analisa rasio keuangan juga dibuat berdasarkan tujuan dari pihak si penganalisis dalam mengevaluasi kinerja perusahaan berdasarkan laporan keuanganya" (Sugiono, 2009:64).

"Laporan keuangan melaporkan aktivitas yang sudah dilakukan perusahaan dalam suatu periode tertentu. Aktivitas yang sudah dilakukan dituangkan dalam angka-angka baik dalam bentuk mata uang rupiah maupun mata uang asing. Angkaangka yang ada dalam laporan keuangan menjadi kurang berarti jika hanya dilihat dari satu sisi saja. Artinya jika hanya dengan melihat adanya. Angka-angka ini akan menjadi lebih apabila dapat kita bandingkan antara satu komponen satu dengan komponen lainya. Caranya adalah dengan membandingkan angka-angka yang ada dalam laporan keuangan dengan laporan keuangan lainya. Setelah melakukan perbandingan dapat disimpulkan posisi keuangan dalam 


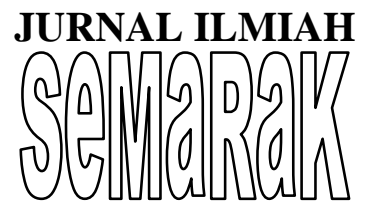

periode tertentu. Pada akhirnya kita dapat menilai kinerja manajemen dalam periode tersebut. Perbandingan ini kita kenal dengan nama analisis rasio keuangan. Rasio keuangan membantu kita untuk mengidentifikasikan beberapa kelemahan dan kekuatan keuangan perusahaan (Keown, 2004:70). Rasio keuangan merupakan penulisan ulang data akuntansi ke dalam bentuk perbandingan dalam rangka mengidentifikasi kekuatan dan kelemahan keuangan perusahaan" (Keown, 2004:70).

"Rasio keuangan menurut James C Van Horne merupakan indeks yang menghubungkan dua angka akuntansi dan diperoleh dengan membagi satu angka dengan angka lainya. Rasio keuangan digunakan untuk mengevaluasi kondisi keuangan dan kinerja perusahaan. Dari hasil rasio keuangan ini akan terlihat kondisi kesehatan perusahaan yang bersangkutan (Kasmir dan Jakfar, 2008:104). Jadi rasio keuangan merupakan kegiatan membandingkan angka-angka yang ada dalam laporan keuangan dengan cara membagi satu angka dengan angka lainya. Perbandingan dapat dilakukan antara satu komponen dengan komponen dalam satu laporan keuangan lainya. Kemudian angka yang diperbandingkan dapat berupa angkaangka dalam satu periode maupun beberapa periode. Hasil rasio ini digunakan untuk menilai kinerja manajemen dalam satu periode apakah mencapai target seperti yang telah ditetapkan. Kemudian dapat dinilai kemampuan manajemen dalam memberdayakan sumber daya perusahaan secara efektif" (Kasmir dan Jakfar, 2008:104).

\section{E. Price Earning Ratio (Y)}

"Berdasarkan cara pengukuran nilai perusahaan di atas, maka pengukuran yang akan digunakan adalah price earning ratio, PER merupakan rasio harga saham suatu perusahaan dengan pendapatan per saham perusahaan tersebut. PER menggambarkan apresiasi pasar terhadap kemampuan perusahaan dalam menghasilkan laba". (Tjiptono dan Darmadji, 2001:139). Menurut Tandelilin (2010:375) menyatakan bahwa "price earning ratio merupakan rasio yang mengindikasikan besarnya rupiah yang harus dibayarkan investor untuk memperoleh satu rupiah earning perusahaan, dengan kata lain price earning ratio menunjukan besarnya harga setiap satu rupiah earning perusahaan dan price earning ratio juga merupakan ukuran harga relatif dari suatu saham perusahaan".

\section{"Price Earning Ratio} mencerminkan hubungan antara harga pasar saham umum (common stock) dan laba per lembar saham. Price Earning Ratio dipandang oleh para investor 


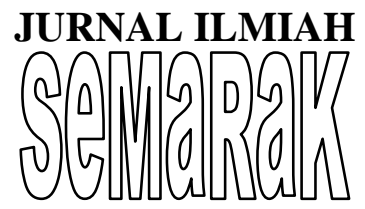

sebagai ukuran kekuatan perusahaan untuk memperoleh laba dimasa yang akan datang (future earning power). Perusahaan yang mempunyai kesempatan tumbuh yang besar biasanya mempunyai Price Earning Ratio yang tinggi, sebaliknya Price Earning Ratio akan rendah untuk perusahaan yang berisiko" (Munawir, 2002:34)

"Price Earning Ratio menunjukkan besarnya harga setiap rupiah earning perusahaan, Disamping itu, Price earning ratio juga merupakan ukuran harga relatif dari sebuah saham perusahaan (Hayati, 2010:2). PER merupakan rasio harga saham terhadap earning per share (EPS), dengan kata lain menunjukkan seberapa besar pemodal menilai harga saham terhadap kelipatan dari earnings" (Jogiyanto, 2003:105).

"Price earning ratio merupakan rasio yang menunjukkan perbandingan antara harga saham di pasar atau harga perdana yang ditawarkan dibandingkan dengan pendapatan yang diterima. Price earning ratio yang tinggi menunjukkan ekspektasi investor tentang prestasi perusahaan di masa yang akan datang cukup tinggi. Adapun rumus dalam menghitung price earning ratio adalah sebagai berikut" (Harahap, 2007:311):

Price Earning Rasio $=\frac{\text { Harga Pasar Saham }}{\text { Laba Bersih Per saham (EPS) }}$

\section{F. Kepemilikan Institusional $\left(\mathbf{X}_{2}\right)$}

"Kepemilikan institusional (INST) adalah kepemilikan saham perusahaan oleh institusi. Kepemilikan institusional yang tinggi akan menimbulkan usaha pengawasan yang lebih besar oleh pihak institusional sehingga dapat menghalangi perilaku oportunistik dari para manajer perusahaan. Kepemilikan institusional diukur dengan proporsi saham yang dimiliki institusional pada akhir tahun dibandingkan dengan jumlah saham yang beredar di perusahaan tersebut" (Moh'd et al. 1998).

INST $=$ Jumlah kepemilikan saham oleh Institusional Seluruh modal saham perusahaan

\section{G. Profitabuility $\left(\mathrm{X}_{3}\right)$}

"Pada dasarnya konsep teori rentabilitas atau profitabilitas ingin mengungkap perbandingan laba dengan modal pada periode tertentu (Riyadi, 2006:155). Rasio profitabilitas merupakan rasio untuk menilai kemampuan perusahaan dalam mencari keuntungan atau laba dalam suatu periode tertentu" (Kasmir dan Jakfar, 2008:114).

Sudana (2011:23) menyatakan bahawa "apa yang dimaksudkan dengan pulangan ekuiti adalah nisbah yang menunjukkan keupayaan syarikat untuk memiliki modal. Harahap (2007: 305) juga berpendapat bahawa "pulangan atas ekuiti adalah nisbah kewangan yang 


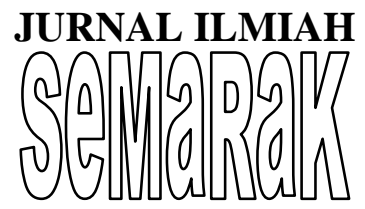

menunjukkan keupayaan syarikat untuk menjana keuntungan selepas cukai dengan menggunakan modal sendiri syarikat".

"Return on equity merupakan rasio yang menunjukan kemampuan perusahaan terhadap modal yang dimiliki (Harahap, 2007:305). Return on Equity (ROE) merupakan rasio keuangan yang menunjukkan kemampuan perusahaan untuk menghasilkan laba setelah pajak dengan menggunakan modal sendiri yang dimiliki perusahaan" (Sudana, 2011:23).

"Return on equity merupakan rasio yang menunjukan kesuksesan manajemen dalam memaksimalkan tingkat pengembalian pada pemegang saham”. Semakin tinggi return on equity maka akan semakin baik, karena memberikan tingkat pengembalian yang lebih besar bagi para pemegang saham (Darsono, 2005:57). Semakin besar nilai ROE maka tingkat pengembalian yang diharapkan investor juga besar. Semakin besar nilai ROE maka perusahaan dianggap semakin menguntungkan. Sehingga perusahaan yang memiliki profitable investment opportunities, maka pasar akan memberikan reward berupa PER yang tinggi (Sartono, 2001:52).

"Return on equity (ROE) merupakan rasio profitabilitas untuk mengukur kemampuan perusahaan dalam menghasilkan laba berdasarkan modal saham yang dimiliki perusahaan. ROE digunakan untuk mengukur tingkat kembalian perusahaan atau efektifitas perusahaan dalam menghasilkan keuntungan dengan memanfaatkan ekuitas yang dimiliki perusahaan. Jika rasio ini meningkat manajemen cenderung dipandang lebih efisien dari sudut pandang pemegang saham. ROE merupakan perbandingan antara laba bersih yang dihasilkan dengan modal sendiri atau equity" (Riadi, 2011:2).

"Return on equity ratio (ROE) yang tinggi akan memberikan sinyal pada investor untuk melakukan investasi ke dalam perusahaan karena perusahaan memiliki prospek yang menguntungkan. Pernyataan di atas sesuai dengan teori signaling, perusahaan dengan prospek menguntungkan akan menginvestasikan setiap modal baru yang masuk dan menghindari penjualan saham" (Wibowo, 2013:6).

"Yang dimaksud dengan return on equity (ROE) dalam penelitian ini adalah laba bersih dibagi total ekuitas (Sugiono dan Untung, 2008:132). Menurut Sudana (2011:22) semakin tinggi return on equity (ROE) menunjukkan bahwa semakin efisien penggunaan modal sendiri (ekuitas) yang dilakukan oleh manajemen perusahaan. Adapun rumus perhitungan return on equity adalah sebagai berikut":

$$
\text { Return On Equity }=\frac{\text { Earning After } T a x}{\text { Total Equity }}
$$


JURNAL ILMIAH

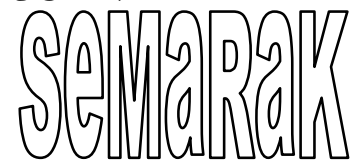

\section{H. Firm Size $\left(\mathbf{X}_{4}\right)$}

Menurut Prabandi dan Rustiana (2007:29), "ukuran perusahaan dapat diartikan sebagai suatu skala dimana dapat diklasifikasikan besar kecil perusahaan dengan berbagai cara antara lain dinyatakan dalam total aktiva, nilai pasar saham, dan lain-lain. Keputusan ketua BAPEPAM No. Kep. 11/PM/1997 menyebutkan perusahaan kecil dan menengah berdasarkan aktiva (kekayaan) adalah badan hukum yang memiliki total aktiva tidak lebih dari seratus milyar, sedangkan perusahaan besar adalah badan hukum yang total aktivanya diatas seratus milyar".

"Pada dasarnya ukuran perusahaan hanya terbagi pada tiga kategori, yaitu perusahaan besar (large firm), perusahaan menengah (medium size), dan perusahaan kecil (small firm)".

"Ukuran perusahaan merupakan fungsi dari kecepatan pelaporan keuangan karena semakin besar suatu perusahaan maka perusahaan akan melaporkan hasil laporan keuangan yang telah diaudit semakin cepat karena perusahaan memiliki banyak sumber informasi dan memiliki sistem pengendalian internal perusahaan yang baik sehingga dapat mengurangi tingkat kesalahan dalam penyusunan laporan keuangan yang memudahkan auditor dalam melakukan audit laporan keuangan. Dengan demikian dapat disimpulkan bahwa kemungkinan ukuran perusahaan dapat mempengaruhi waktu penyelesaian audit" (Rachmawati, 2008:3).

Menurut Brigham dan Houston (2010:117) "ukuran perusahaan adalah rata-rata total penjualan bersih untuk tahun yang bersangkutan sampai beberapa tahun, dalam hal ini penjualan lebih besar daripada biaya variabel dan biaya tetap maka perusahaan akan menderita kerugian".

"Ukuran perusahaan dinyatakan sebagai determinan dari struktur keuangan dalam hampir setiap studi dan untuk sejumlah alasan yang berbeda. Pertama ukuran perusahaan dapat menentukan tingkat kemudahan perusahaan memperoleh dana dari pasar modal. Perusahaan kecil umumnya kekurangan akses ke pasar modal yang terorganisir, baik untuk obligasi maupun saham. Kedua ukuran perusahaan menentukan kekuatan tawar-menawar (bargaining power) dalam kontrak keuangan. Perusahaan besar biasanya dapat memilih pendanaan dari berbagai bentuk utang, termasuk penawaran spesial yang lebih menguntungkan dibandingkan yang ditawarkan oleh peusahaan kecil. Semakin besar kemungkinan jumlah uang yang terlibat, semakin besar kemungkinan pembuatan kontrak yang dirancang sesuai dengan preferen kedua pihak sebagai ganti dari penggunaan kontrak standar utang. Ketiga ada kemungkinan pengaruh skala dalam biaya dan return membuat perusahaan yang lebih besar dapat memperoleh lebih banyak dana. Ukuran 


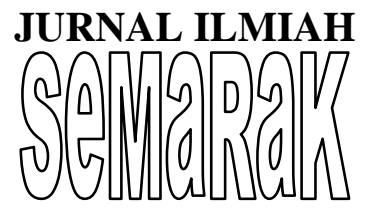

perusahaan dapat ditentukan berdasarkan laba, aktiva, tenaga kerja, dan lain-lain, yang semuanya berkorelasi tinggi" (Sawir, 2004:101)

"Ukuran perusahaan merupakan variabel kontrol yang banyak digunakan dalam penelitian, hal ini disebabkan karena banyaknya keputusan investasi dipengaruhi oleh ukuran perusahaan. Ukuran perusahaan biasanya diproksikan dengan total asset, karena nilai asset yang cukup besar maka ukuran perusahaan akan diperhalus dengan melakukan Log (Asset) atau Ln (Asset). Ukuran perusahaan (Size) adalah ukuran besar kecilnya suatu perusahaan. Perusahaan yang lebih besar cenderung memiliki sumber permodalan yang lebih terdiversifikasi sehingga ukuran perusahaan (Size) merupakan kebalikan keuntungan terjadinya kebangkrutan. Pengukuran ukuran perusahaan dilakukan dengan menggunakan rumus" (Asnawi dan Wijaya, 2005:274):

\section{Size $=$ Ln $($ total aktiva $)$}

\section{Hipotesis dari Penelitian}

"Hipotesis adalah suatu dugaan dalam suatu penelitian yang menjadi patokan dalam suat analisis. Adapun hipotesis yang diuji yakni sebagai berikut":

1. $H_{0}$ : kepemilikan institusional tidak memiliki pengaruh terhadap price earning ratio.

$$
\begin{aligned}
\mathrm{H}_{\mathrm{a}} & \text { : kepemilikan institusional } \\
& \text { memiliki pengaruh terhadap } \\
& \text { price earning ratio. }
\end{aligned}
$$

2. $\mathrm{H}_{\mathrm{o}}$ : profitability tidak memiliki pengaruh terhadap price earning ratio.

$\mathrm{H}_{\mathrm{a}}$ : profitability memiliki pengaruh terhadap price earning ratio.

3. $\mathrm{H}_{\mathrm{o}}$ : firm size tidak memiliki pengaruh terhadap price earning ratio.

$\mathrm{H}_{\mathrm{a}}$ : firm size memiliki pengaruh terhadap price earning ratio.

4. $H_{\mathrm{o}}$ : variabel kepemilikan manajerial, kepemilikann innstitussional, proffitability dan firm size tidak memiliki pengaruh terhadap price earning ratio.

$\mathrm{H}_{\mathrm{a}}$ : variabel kepemilikan manajerial, kepemilikann innstitussional, proffitability dan firm size memiliki pengaruh terhadap price earning ratio.

\section{METODOLOGI PENELITIAN}

“Objek dalam penelitian ini adalah perusahaan manufaktur yang terdaftar di bursa efek Indonesia (BEI). Metode yang digunakan dalam kajian ini adalah kes kajian yang merupakan salah satu deskriptif penelitian, dengan penelitian ini diharapkan dapat menyampaikan secara mendalam variables yang akan dapat menggambarkan analisa kepemilikan manajerial, kepemilikan institusional, profitability dan firm size terhadap price earning ratio.

"Data yang digunakan dalam penelitian ini, yang bertujuan untuk menggambarkan dan menganalisa, 


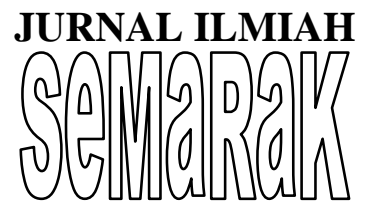

diperoleh dari sekunder data yang bersifat kuantitatif. Data sekunder adalah data yang informasinya diperoleh secara tidak langsung dari syarikat. "Data sekunder merupakan "sumber data penelitian yang diperoleh peneliti secara tidak langsung melalui perantara (diperoleh dan dicatat oleh pihak lain)". "Data sekunder berupa laporan kewangan dari syarikat kewangan yang diudit pada perusahaan LQ 45 per 31 Disember 2011 - 2013".

"Sampel yang digunakan dengan teknik puurposive sammpling. Kaedah puurposive sammpling adalah sampel diambil berdasarkan kriteria tertentu untuk mendapatkan sampel yang sesuai dengan tujuan penyelidikan (Yama dan Adityawati, 2009)". Sampel dalam kajian ini ditentukan berdasarkan beberapa kriteria atau pertimbangan seperti berikut: "1) Perusahaan LQ-45 yang terdaftar di Bursa Efek Indonesia dan tetap pada perusahaan LQ-45 dalam kurun waktu 2011 sampai 2013, 2) Perusahaan mempublikasikan laporan keuangan yang telah diaudit dengan menggunakan tahun buku yang berakhir pada tanggal 31 Desember, 3) Laporan keuangan perusahaan tidak menunjukan adanya saldo total equitas yang negatif dan akan mengalami kerugian selama periode tahun penelitian (2011 - 2013)".

"Teknik pengumpulan data menggunakan analisis penyata kewangan. Sampel yang digunakan sebagai objek penyelidikan ialah 36 syarikat pembuatan yang disenaraikan di situs idx.co.id".

\section{HASIIL DAAN PEMMBAHASAN}

\section{A. Analissa Objjek Peenelittian}

\section{Sejaarah Paasar Mooddal Di Indonesaian}

"Berdasarkan sejarah pasaran modal sebelum kemerdekaan Indonesia, pasar modal atau bursa saham telah muncul sejak era kolonial Belanda dan tepat pada tahun 1912, ketika pasar modal didirikan oleh pemerintah Hindia Belanda untuk kepentingan penjajah".

"Perkembangan pertumbuhan pasaran modal tidak berlaku seperti yang diharapkan. Dalam beberapa tempoh aktiviti pasaran modal yang mengalami kekosongan yang disebabkan oleh beberapa faktor seperti Perang Dunia I dan II, Kerajaan Republik Indonesia telah memulihkan semula pasaran modal pada tahun 1977 dan beberapa tahun kemudian pasaran modal mengalami pertumbuhan bersama dengan pelbagai insentif dan peraturan yang dikeluarkan oleh kerajaan".

\section{Perusahaan LQ 45 di Bursa Efekk Indonesia}

Indeks LQ 45 adalah nilai kapitalisasi pasar dari 45 saham yang paling likuid dan memiliki nilai kapitalisasi yang besar hal itu merupakan indikator likuidasi. Indeks LQ 45, menggunakan 45 saham yang 
terpilih berdasarkan Likuiditas perdagangan saham dan disesuaikan setiap enam bulan (setiap awal bulan Februari dan Agustus). Dengan demikian saham yang terdapat dalam indeks tersebut akan selalu berubah. Beberapa kriteria - kriteria seleksi untuk menentukan suatu emiten dapat masuk dalam perhitungan indeks LQ 45 yaitu sebagai berikut: (lihat http//www.idx.co.id, diakses tanggal 14 Mei 2015).

a. Kriteria yang pertama adalah:

1) Berada di TOP $95 \%$ dari total rata - rata tahunan nilai transaksi saham di pasar reguler.

2) Berada di TOP $90 \%$ dari rata rata tahunan kapitalisasi pasar.

b. Kriteria yang kedua adalah:

1) Merupakan urutan tertinggi yang mewakili sektornya dalam klasifikasi industri BEI sesuai dengan nilai kapitalisasi pasarnya.

2) Merupakan urutan tertinggi berdasarkan frekuensi transaksi.

\section{B. Hasiil Peenemuan dann Pemmbahasan}

1. Hassil Penggujian Assumsi Klassik

a. Hassil Peengujian Norrmalitas

Daata

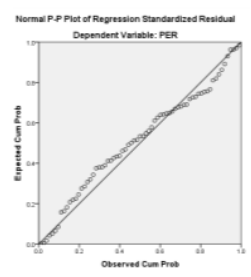

Gambar 1

Penngujian Noormalitas Data
"Dari grafik di atas dapat dilihat bahwa data penelitian memiliki penyebaran dan distribusi yang normal karena data memusat pada nilai rata-rata dan median atau nilai plot PP terletak digaris diagonal, maka dapat dikatakan bahwa data tersebut berdistribusi normal".

\section{b. Hasil Ujji Multikollinearitas}

\section{Tabel 1}

Hasil Uji Multikollinearitas

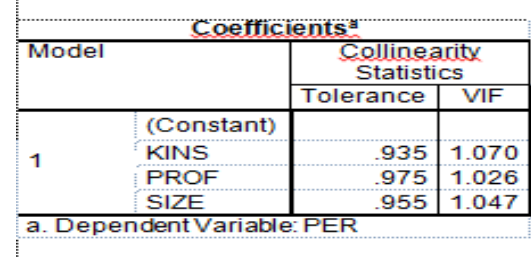

"Nilai VIF yang diperbolehkan di bawah 10 dan memiliki nilai tolerance di atas 0,10. Maka data di atas dapat dipastikan tidak terjadi gejala multikolinearitas. Karena data di atas menunjukan bahwa nilai VIF sebesar 1,070 untuk variabel KINS, 1,026 untuk variabel PROF dan 1,047 untuk variabel SIZE lebih kecil dari 10. Dan nilai tolerance di atas 0,10 yaitu sebesar 0,935 untuk variabel kins, 0,975 untuk variabel PROF dan 0,955 untuk variabel SIZE".

\section{c. Hasil Pengujian Autokorelasi}

Tabel 2 Penguujian Autokoorelasi 


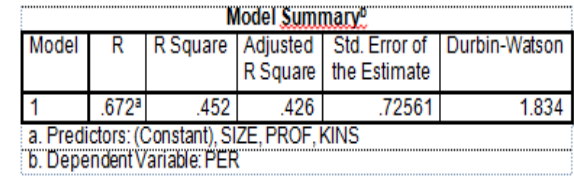

"Terlihat bahwa nilai Durbin Watson (d) sebesar 1,834 nilai ini akan dibandingkan dengan nilai tabel dengan menggunakan nilai signifikansi 5\%, jumlah sampel (n) 69 dan jumlah variabel independen (k) adalah 3. Maka dari tabel didapat nilai du $=1,701$ dan $4-\mathrm{du}=4-$ $1,701=2,299$. Olleh kareena nilaai $\mathrm{du}<\mathrm{d}<4$-du atau $1,701<1,834<$ 2,299 maka dapat disimpulkan tidak ada autokorelasi”.

\section{d. Hassil Uj.ji Heeteroskedastisitas}

\section{Gambar 2}

\section{Hassil Ujji Heteroskedastisitas}

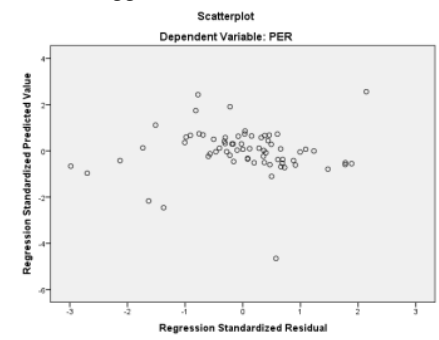

"Hasil pengolahan data di atas bahwa terlihat titik-titik menyebar di atas dan di bawah angka nol pada sumbu $\mathrm{Y}$ dan tidak terlihat pola tertentu. Dengan demikian pada persamaan regresi linier berganda dalam model ini tidak ada gejala atau tidak ada heteroskedastisitas".

\section{Hassil Koeefisien Reegresi Liinier Beerganda}

\section{a. Haasil Koeefisien Addjusted $\boldsymbol{R}^{2}$}

\section{Tabel 3}

Hassil Kooefisien Adjjusted $\mathbf{R}^{2}$

\begin{tabular}{|l|r|r|r|r|r|}
\hline Model & $R$ & R Square & $\begin{array}{l}\text { Adjusted } \\
\text { R Square }\end{array}$ & $\begin{array}{r}\text { Std. Error of } \\
\text { the Estimate }\end{array}$ & Durbin-Watson \\
\hline 1 & $.672^{\text {s }}$ & .452 & .426 & .72561 & 1.834 \\
\hline a. Predictors:(Constant), SIZE, PROF, KINS \\
\hline b. Dependent Variable:PER
\end{tabular}

"Berdasarkan kepada tabel di atas diketahui nilai Adjusted $R$ square sebesar 0,426 (42,6\%), Ini menunjukkan bahwa dengan menggunakan model regresi yang didapatkan dimana variabel independen yaitu kepemilikan institusional, profitability dan firm size memiliki pengaruh terhadap variabel price book value sebesar $42,6 \%$. Sedangkan sisanya $57,4 \%$ dijelaskan dengan faktor atau variabel lain yang tidak diketahui dan tidak termasuk dalam analisis regresi ini, seperti price earning ratio, firm size dan lain-lain".

\section{b. Hasil Koefisien Perrsamaan} Regressi Liniier Bergaanda

"Analisis regresi linier berganda ialah ujian yang digunakan untuk menentukan sejauh mana tahap pengaruh antara pembolehubah bebas (kepemilikan institusiional, profitability dan firm size) ke atas pembolehubah bergantung (nilai buku harga). Hasil daripada pengaruh regresi linear berganda bagi kepemilikan institusiional, profitability dan firm 
size terhadap price earning ratio adalah seperti berikut:

Tabel 4

Koefiisien Persamaan Regresi Pelbagai Linear

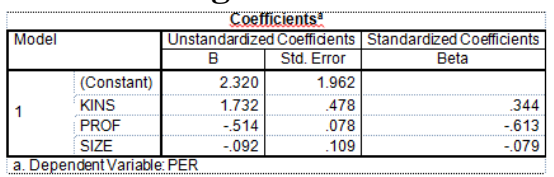

"Jadual di atas boleh

dirumuskan persamaan regresi untuk menentukan kesan set peluang pelaburan, dasar dividen dan pulangan ekuiti ke arah nilai buku harga seperti berikut":

$\mathrm{Y}=\mathrm{a}+\mathrm{bx_{1 }}+\mathrm{bx}_{2}+b \mathrm{x}_{3}+\mathrm{bx}$

$Y=2,320+1,732 X_{1}-0,514 X_{2}-$ $0,092 \mathrm{X}_{3}$

Keterangan:

$\mathrm{Y}$ : Price earning ratiio

$\mathrm{X}_{1}$ : Kepemilikan institusional

$\mathrm{X}_{2}$ : Proofitability

$\mathrm{X}_{3}$ : Fiirm sizie

"Koefisien persamaan regresi linear berganda di atas boleh ditafsirkan sebagai pekali regresi malar 2,320 yang menunjukkan bahawa jika peluang pelaburan yang ditetapkan berubah", "dasar kepemikan institusional, profitability dan firm size adalah sifar (konstan), maka price earning ratio akan naik sebesar 2.320 unit. Perhatikan bahawa pembolehubah lain dianggap malar". "Pelbagai pemboleh ubah menetapkan 1.732 menunjukkan bahawa jika pemboleh kepemilikan institusional meningkat sebanyak 1 unit, ia akan meningkatkan price earning ratio sebanyak 1,732 unit". "Profitability sebesar -0,514 menunjukkan bahawa jika pembolehubah profitability meningkat sebanyak 1 unit, ia akan menurunkan price earning ratio sebanyak $0,514 \quad$ unit”. "Pembolehubah firm size sebanyak 0,092 menunjukkan bahawa jika pulangan atas vaiabel firm size meningkat sebanyak 1 unit, ia akan menurunkan price earning ratio sebanyak 0,092 unit, dengan syarat bahawa pembolehubah lain dianggap tetap"

\section{Ujji Hipotesis}

\section{a. Uji Statistik F (Simultan)}

"Ujian F dilakukan untuk melihat kesan pemboleh ubah set yang berpotensi pelaburan, dasar dividen dan pulangan ekuiti keseluruhan pada pembolehubah nilai buku harga. Berikut adalah keputusan ujian serentak, keputusan ujian ANOVA diperolehi seperti berikut":

\section{Tabel 5}

Hasil Uji Statistik F (Simultan)

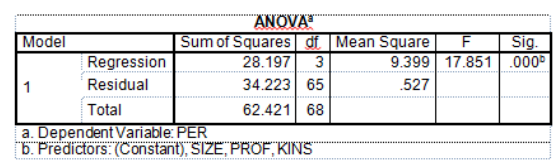

Daripada data di atas memperoleh nilai signifikan 0,000 bermakna bahawa peruntukan 


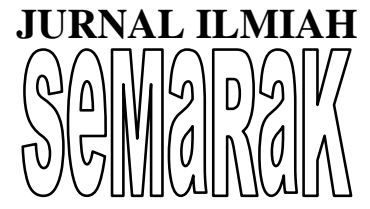

nombor dua terpakai dalam kajian ini yang Ho ditolak dan Ha diterima. Keputusan ujian $\mathrm{F}$ ini menyatakan bahawa keputusan ujian serentak di atas adalah benar.

Dalam kajian ini, nilai $\mathrm{F}$ yang dikira daripada 17,851 adalah lebih tinggi daripada nilai $F_{\text {table }} 2,75$. Boleh disimpulkan bahawa terdapat kesan linear antara pembolehubah bebas dan pembolehubah bergantung.

\section{b. Ujji t (Ujji Secaara Paarsial)}

Tabel 6

Ujji t (Uji Secara Parsial)

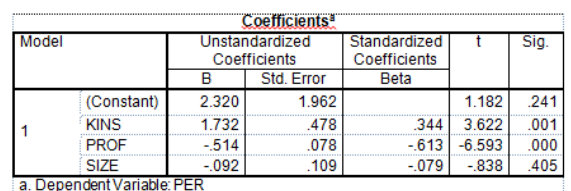

"Berdasarkan keputusan ujian $\mathrm{t}$, didapati bahawa variabel bebas (kepemilikan institusional dan profitability) mempunyai kesan separa pada price earning ratio", sedangkan variabel firm size tidak memiliki pengaruh terhadap price earning ratio".

\section{KESIIMPULAN DANN SARRAN}

\section{A. Kesimmpulan}

Kajian ini dijalankan untuk menentukan kesan kepemilkan institusional, profitability dan firm size pada price earning ratio. Berdasarkan hasil penyelidikan yang dijelaskan dalam bab sebelumnya, beberapa kesimpulan dapat diambil seperti berikut:

1. Hasil kajian menyatakan bahawa sebahagian atau berdasarkan keputusan ujian $t$ menunjukkan bahawa pemboleh kepemilikan institusional yang berpotensi pelaburan mempengaruhi price earning ratio.

2. Hasil kajian menyatakan bahawa sebahagian atau berdasarkan hasil uji t menunjukkan bahawa profitability mempengaruhi price earning ratio.

3. Hasil kajian menyatakan bahawa sebahagian atau berdasarkan hasil ujian $\mathrm{t}$ menunjukkan bahawa firm size tidak mempengaruhi price earning ratio.

4. Hasil kajian menyatakan bahawa secara serentak atau berdasarkan keputusan ujian $\mathrm{F}$ menunjukkan terdapat pengaruh yang signifikan antara kepemilikan institusional, profitability dan firm size terhadap price earning ratio

\section{B. Saran}

Hasil kajian ingin memberikan beberapa cadangan yang dapat disampaikan, iaitu:

1. Bagi Investor

Hasil penelitian menyatakan bahwa terdapat pengaruh antara kepemilikan institusional dan profitability terhadap price earning ratio. Hasil penelitian 
menyatakan bahwa bagi investor harus lebih teliti lagi dalam menginvestasikan modalnya dengan memperhatikan bagaimana fluktuatif dari nilai kepemilikan manjerial institusional dan profitabuility, sehingga investor akan meraih keuntungan yang lebih baik lagi.

2. Bagi Akademik

Hasil penelitian menyatakan bahwa terdapat pengaruh antara kepemilikan institusional dan profitability terhadap price earning ratio. Dengan hasil penelitian maka diharapkan dapat menjadi acuan bagi mahasiswa untuk melakukan penelitian selanjutnya mengenai price earning ratio dalam meningkatkan keuntungan dalam berinvestasi, sehingga akan menambah wawasan bagi mahasiswa dalam studi manajemen keuangan. Hasil penelitian akan bermanfaat bagi mahasiswa dalam penemuan teori mengenai peningkatan price earning ratio yang akan berakibat pada tingkat keuntungan dalam investasi.

\section{Bagi Peneliti}

Hasil menyatakan bahwa kepemilikan institusiobnal dan profitabiity sangat penting dalam meningkatkan price earning ratio. Adapun implikasi bagi penelitian selanjutnya adalah sebagai berikut:

a. Menambahkan jumlah sampel penelitian sehingga menambah sebuah penelitian yang lebih baik.

b. Menambahkan jumlah variabel independen yang dapat mempengaruhi price earning ratio, seperti earning per share, struktur modal, dan dividend payout ratio.

c. Menambahkan periode waktu penelitian sesuai dengan tahun penelitian sehingga penelitian lebih up to date.

\section{DAFTAR PUSTAKA}

Anggraini, Dina, "Pengaruh Good Corporate Governance Terhadap Nilai Perusahaan Pada Perusahaan Textile, Garment yang Terdaftar di Bursa Efek Indonesia(BEI) Periode 2009-2012”, Jurnal Akuntansi, Tanjung Pinang, 2012.

Brigham, Eugene $\mathrm{F}$ and Joel F.Houston, "Dasar-Dasar Manajemen Keuangan, alih bahasa Ali Akbar Yulianto”, Buku satu, Edisi sepuluh, PT. Salemba Empat, Jakarta, 2006.

Brigham, Eugene F and Joel F.Houston, "Dasar-dasar Manajemen Keuangan", Salemba Empat, Jakarta, 2010.

Darsono dan Ashari, "Pedoman Praktis Memahami Laporan Keuangan”, Andi, Yogyakarta, 2005.

Fuad, M, "Pengantar Bisnis”, PT Gramedia Pustaka Utama, Jakarta, 2006.

Ghozali, Imam. "Aplikasi Analisis Multivariate dengan Program SPSS", Badan Penerbit Undip, Semarang, 2009.

Harahap, Sofyan Syafri, "Analisis Kritis atas Laporan Keuangan”, Raja Grafindo, Persada, Jakarta, 2007. 


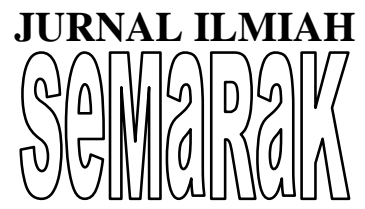

Hayati, Nurul, "Faktor-Faktor yang Mempengaruhi Price Earning Ratio (PER) Sebagai Salah Satu Kriteria Keputusan Investasi Saham Perusahaan Real Estate dan Property di Bursa Efek Indonesia”, Jurnal Manajemen dan Bisnis, April 2010, Volume 11 Nomor 1, Banjarmasin, 2010.

Jogiyanto, "Teori Portofolio dan Analisa Investasi”, BPFE, Yogyakarta, 2003.

Kasmir dan Jakfar, "Studi Kelayakan Bisnis", Edisi-2, Kencana, Jakarta, 2008.

Keown, J Arthur, dkk, "Dasar - Dasar Manajemen Keuangan”, Salemba Empat, Jakarta, 2004.

Mardiyanto, Handono, "Intisari Manjaemen Keuangan”, Grasindo, Jakarta, 2008.

Munawir, "Analisis Laporan Keuangan", Edisi Ke-4, Liberty, Yogyakarta, 2002.

Nasaruddin, Indoyama dan Septian Adityawati. "Perbandingan Analisis Karakteristik Perusahaan, Industri dan Ekonomi Makro Terhadap Return dan Beta Saham (Studi Kasus IHSG dan JII Tahun 2003 - 2008”, Jurnal Ekonomi UIN Syarif Hidayatullah Jakarta, 2009.

Riadi, Elon Davit, "Pengaruh Faktor Debt To Equity Ratio, Return On Equity Dan Total Assets Terhadap Price Earning Ratio (PER)Pada Perusahaan Otomotif", Jurnal Ekonomi dan Bisnis, Vol. 2, Nomor 3, Tahun 2011, Padang, 2011.

Riyadi, Selamet. "Banking Assets and Liability Management". Edisi 3. JLembaga Penerbit Fakultas Ekonomi Universitas Indonesia, Jakarta, 2006.

Robinson, Pearce, "Manajemen Strategis", Salemba Empat, Jakarta, 2008.

Ross,Stephen A.,et. All., "Fundamentals of Corporate Finance", Sixth Edition,
The McGraw Hill Company,New York, 2003.

Sari, Indah Permata, "Analisis Faktor-Faktor Yang Mempengaruhi Praktik Penerapan Internet Financial Reporting (IFR) Pada Perbankan Di Indonesia”, Jurnal Akuntansi, 2011.

Sartono, Agus, "Manajemen Keuangan Teori dan Aplikasi", BPEF, Yogyakarta, 2001.

Sawir, Agnes, "Analisis Kinerja Keuangan dan Perencanaan Keuangan Perusahaan”, PT. Gramedia Pustaka Utama, Jakarta, 2004.

Sudana, I Made "Manajemen Keuangan Perusahaan : Teori dan Praktik", Erlangga, Jakarta, 2011.

Sugiono, Arief dan Edy Untung, "Panduan Praktis Dasar Analisis Laporan Keuangan”, Grasindo, Jakarta, 2008.

"Manajemen Keuangan Untuk Praktisi Keuangan, Grasindo, Jakarta, 2009.

Suharyadi dan Purwanto, S.K, "Statistika untuk Ekonomi dan Keuangan Modern Buku 1", Salemba Empat, Jakarta, 2009.

Sulistyanto, Sri, "Manajemen Laba Teori dan Model Empiris", Grasindo, Jakarta, 2008. 